\title{
DOUBLE JEOPARDY
}

\author{
CATHOLIC AND IRISH
}

\section{PATRICK O'FARRELL}

$\mathbf{T}$

he term 'Anglo-Celtic' is commonly applied, especially by persons to which neither ethnicity applies, to describe the predominant present character of Australia's population. It is a grossly misleading, false and patronising contemporary convenience, one crassly presentoriented. Its use removes from consciousness and recognition a major conflict fundamental to any comprehension, not only of Australian history but of our present core culture. Mainstream contemporary Australia is not to be predicated as some sort of static, immutable monolith. It evolved, and evolves, under tension and stress, the product of two centuries of innumerable complex human transactions, accommodations, competing value systems, grudging concessions, tolerated diversities, all within sensed or instinctive social limits. And all under the umbrella of the development of the Western cultural tradition - the rule of law, political democracy and individual freedom, the secular state, toleration of diversity, economic capitalism, change and modernity. There was, in both Catholic and Protestant, Irish and English, Australia, a basic broad agreement on the practices and institutions embodying these: sectarian conflict was within implicit boundaries, about ways of sharing, controlling, operating, prioritising generally accepted organisational and behavioural propositions, not about what such basic institutions and values actually were.

That Australian society should have achieved harmony and prosperity is no accident. Nor should it be taken for granted, as it so often is. The present is not immutable or immune from damage or destruction. It is itself a hard-won and relatively recent solution to the problem of a legacy of bitter and divisive religious differences between Protestants and Catholics. At least the terms 'Protestant' and 'Catholic' are less dismissive of the actualities of history: no conflatory term has been suggested to avoid that embarrassing unpleasantness. Religious difference and conflict have simply been moved well off any stage of contemporary attention or even comprehension.

The abandonment of personal religion has had profound disabling effects not only on interpreting the past, but on perceiving the constituent underlying assumptions operating in the present. Australia has recently battled its way out of the dangers associated with divisive religious mindsets into agreement on secular neutrality. What emerged was not the abolition of bigotry but its containment. 
The achievement of a religiously reconciled Australia dates from the 1970s. The idea that Australia was riven by ethnic and religious conflict and division, embodied in destructive individual animosity and periods of extreme social fragility, is now not one easily accepted or even recognised. Why? Because Irish-English hostility has been subsumed-but only very recently, the 1980s, 1990s - into a sense of Australian commonality. And because religion as any thinkable influential social factor has been buried, both by dismissive secularism, and religion's embrace of the whole paraphernalia of the politically correct: it is an irrelevance and an embarrassment now, a private aberration, and should always have been so.

That is not how things began, but they began in such a way as to lead, if only after protracted travail, to a happy eventual outcome. Australia was the first secular, state-controlled society established in modern times: in a sense what has happened has been a two-century painful exploration which has returned to its origins. Those origins were secular, but only in the sense of not being religious, not in the sense of being militantly anti-religious - an important distinction often blurred. Neutral, for the common good.

Consider what happened, and its radically formative consequences. Here was a state-controlled society before its time. Up until Australia's foundation, it was axiomatic that Church and state were intimately linked. The ruler enforced the true religion. Until the 18 th century, it was assumed that the state would, indeed must, discriminate between religious traditions. The idea that any other course was possible was first born in 17th century America and first given significance by the American Constitution in 1787, in situations where religious monopoly proved impossible to enforce. Toleration first appeared, not as a desirable virtue, but as the only possible solution to intractable problems of religious difference. Australia emerges as the first post-American society, the first place where toleration was viewed as an operating principle rather than arrived at reluctantly as a lastresort pragmatic necessity: the contrast is crucial in terms of the way in which religion is culturally regarded. Australia is also a society subsequent to the French Revolution of 1789 , but in it the role of religion was very different. Its disposition was militantly anti-religious, anything but neutral, and religion remained in French history central to social and political concern as a matter of vigorous and vehement conflict.

In Australia, the churches were cast - and cast themselves - in a suppliant and subservient role. Witness the Church of England's unsuccessful attempt to claim the position of Established Church. Witness the Catholic Church's bid for liberty and equality. Who was the arbiter in this, the determining authority? The state, in the person of the colonial governor. And what was the disposition of that state in regard to religious adherence? Neutrality. Seen religiously, the state had arrogated to itself the power to be above religion, to have authority superior to it - heresy indeed. But the state was acting for the best of reasons - not merely to avoid the disruption of civil society by endemic sectarian conflict, but to positively support all religion, which it did in NSW until 1862. This is the governmental and societal context, an atmosphere conducive to fair play, and an instinctive moderate mind-frame, which 
mutes and controls Australia's sectarian history.

About a quarter of Australia's population at any given time up to say the 1970s, was subject to denigration, hostility, prejudice and discrimination, both personal and public. The grounds were both religious and racial. It is extremely difficult, if not impossible to distinguish or separate these two grounds for bigotry, particularly as they were interwoven with a third, a socio-economic dimension of class difference and antagonism. The prevailing community image of the Catholic was not only that of a deluded, superstitious, priest-ridden, disloyal and dangerous Papist, loyal only to Rome. He was also a dirty pig-loving, ignorant, subhuman Irish rebel; and a member of the lower orders, with all their contemptible characteristics which made them both offensive and a menace. These stereotypes - and the counter-reaction of the persons so categorised - were built into historical experience and imported into Australia from Great Britain and Ireland from 1788 onward. They constituted not only obvious declared animus, but also what J. H. Newman called 'a stain on the imagination', cultural conditioning that lives strongly still. An illustration. I would like to write the hidden history of the flicker I see behind some people's eyes when I say my name. My most intense recollection of that was in Belfast in 1992 when my wife and I were introduced, on an official occasion, to two Unionist members of the Northern Ireland parliament. Their eyes showed me more about Irish sectarianism than any words ever could. About hatred, disdain, anticipation and the conviction that such feelings would be reciprocated.
Australian sectarianism derived from the legacy of 16th century events, that is, the English variant of the Protestant Reformation, and the English conquest of Ireland. These generated divisive issues both massive and potent-nationalism, political power, religious principle and belief, all seen in the context of fear. The Reformation divided Christendom into those who supported the authority and doctrines of the Papacy and the Roman Catholic Church, and those who violently rejected this, and supported independent national state churches, and/or the Bibleoriented teachings of the reformers. The English conquest of Ireland from 1534, sought to dispossess the Irish of their land and impose on the Catholic Irish, English government and Protestant religion. Very importantly for subsequent history, English propaganda sought to morally vindicate this invasion with an ideology of justifiable colonial subjection. So the Irish became, forever after, seditious Catholic barbarians, sub-human anthropoids, violent, dirty, ignorant, on whom it was a necessary duty to impose English rule, civilisation and religion. For their own good: their resistance proved their inferiority and primitive savagery.

Australia was heir to three centuries of bitter and violent religious and racial confrontation. The penal colony was not only a prison but embodied those sectarian assumptions in its structures and administration: its governance was British and Protestant. But the philosophy of the Enlightenment had weakened religion's intellectual hold, and the power and influence of the Church of England was in serious decline. Although the colony's derivation implied institutional sectarianism, practicality and common sense dictated that it 
not be rigidly enforced: to impose it on the one-third of the convict population which was Irish Catholic raised major questions of colonial security and stability. Authority saw religion as a force supporting and encouraging social order, and clergy as moral policemen, in a sensitive prison situation. Some degree of recognition of Catholic worship was a practical necessity.

Provided Catholics played the game, were not too pushy. Which of course evangelical Anglicans thought they were. To which the government response was in Governor Bourke's 1836 Church Act, an attempt to arbitrate towards religious equality.

Up to this time, the hostility towards Catholicism was on religious grounds: it was idolatrous, inquisitorial, opposed to Bible reading, jesuitical, that it was doctrinally false and dangerous. This view endured. But from the 1840s it was massively supplemented by the other ingredient in the sectarian stew, anti-Irishism. Increasing numbers of Irish Catholic immigrants prompted the reaction summed up in the title of John Dunmore Lang's 1841 pamphlet The Question of Questions: or is this Colony to be Transformed into a Province of Popedom? This question was to be the enduring sectarian question, right down to Dr H. V. Evatt's denunciation of the Movement in 1954. It expressed a fear and suspicion of potential Irish Catholic threats to the future composition and character of Australian society. The influx and activities (often assertive and truculent) of Irish Catholics were a standing menace to the majority assumption that British Protestant values and outlook would prevail harmoniously in a racially homogenous Australian society.
Major issues of social organisation and control-immigration, education, political organisation and power, national loyalty-emerged from the 1840s. A more complex and sophisticated society grew from convict and pioneering beginnings. So too grew contention over what the present and future Australia would be, and who would control it. There were two over-arching world views in conflict, Protestant and Catholic, which would subsume all other considerations and engage passionate emotion, high principle, loyalty, tribalism, and a sense of history. That third world view, Enlightenment reason and scepticism, which promoted a secular society, was in abeyance, until the others had exhausted their aggressive dynamic in conflict. Sectarianism was the result and product of the idea that there should be one Australian identity, and that of a particular kind. To the extent that it expressed legitimate differences of belief and values, the Catholic-Protestant divide represented appropriately contending visions of truth: to the extent that these beliefs were made the vehicles of intolerance, ignorance, fear, discrimination, suspicion and mistrust they inflicted human damage and encouraged social malaise.

The central issue was always who should possess political power. The first colonial elections of 1843 saw rival Catholic and Protestant candidates, clerical involvement, Irish and Orange mobs rioting - and vehement press disapproval of Catholicism as selfish, menacing, and at odds with the rest of society. But Catholics demonstrated then as they did in Australia thereafter, that there was no such thing as a monolithic Catholic vote. They were split, even fragmented, and their votes could not be directed either by Catholic 
clergy or by Irish nationalists. They voted on local issues and personalities, the ordinary range of political considerations. The Irish Catholic reaction to sectarian attack was always informed by the overriding wish to belong, assimilate, rather than stay apart. Catholics were never united politically, but Protestants always thought they were: it was a prejudice impervious to denial or contrary demonstration, feeding on itself and generating bigotry in return.

Bigotry in Australia was at its most publicly intense between 1880 and 1925 . What were the major issues? Education. The education question was answered in a secular way by various colonial governments, ending with the NSW Act in 1880. The general expectation was that Catholic schools would die through lack of funding. Their continuance remained an enduring sectarian grievance: Catholics demanded state aid. Protestants saw them as socially divisive. Then there was Ireland, its turbulent history a great disruptor of colonial harmony. In 1883 the Sydney Morning Herald pronounced, ' . . . an Irish Australian is a creature of whom we cannot possibly conceive. He is or he is not one of us ...' This is mild in comparison with the venom and fury associated with the prolonged storm centred on the 1916 Irish rebellion, the conscription referenda, and Archbishop Mannix. The Irish were malignantly dangerous, arrantly subversive, patently disloyal, however much they protested their Australian patriotism. No one thought to consider or ever grasp the fact that for Catholics in Australia Ireland was the medium, not the message. It was a convenient allegory, the language through which local points were made, a salutary example of the potential extremes to which tendencies within the Australian commonality might develop. Ireland's history demonstrated the predicament of Australia's Catholics writ large. NSW topped this off with an aggressively Protestant anti-Catholic Nationalist government, defeated in 1925. The peace that followed was a standoff of exhaustion and segregation.

These sectarian years were the time when Australia's social fabric was put to the test. It held, but it is easy to overlook the very real dangers that it might not. In 1900, the main topic of public interest was not Federation (remember, only half those eligible bothered to vote) but a spectacular sectarian case. And that the Catholic-Labor alignment, so central to Australian political history, was a reflection not of economic determinism, but of the militantly anti-Catholic bigotry. Of the nonLabor parties: Catholics had nowhere else politically to go. The Catholic claim to loyalty to Australia in 1914-18 strained to the limit the sufferance of those who thought in terms of British Empire.

Why did Australia avoid those lapses into sectarian violence that marred the histories of other Western countries?

The basic reason lies in the pragmatic nature of its foundation and its continuance as an open society and economy. From the beginning, Irish Catholic convicts, when freed, could move to ownership, prosperity and respectability, a path followed by migrants thereafter. Pioneering circumstances in a vacant land rendered irrelevant old world divisions and hierarchies. Free immigrants experienced months of religious mix: the voyage out was an ecumenical experience. Bigotry and racial denunciation on arrival was objectionable, but had no practical bite: in colonies starved of labour, few employ- 
ers had the luxury of being able to avoid Irish Catholic workers. When faced with the notice 'No Irish Need Apply' they went elsewhere, set up their own business or professional practice: here was a society of ample resource and choice - and space to move. The natural petty frictions, the transaction costs of daily living, inevitable in religious and cultural mix, were minimised by dispersal and a population constantly mobile. Distance and movement bred tolerance: in rural areas, St Patrick's Day was everybody's day.

It was the close living of cities that lent itself to tensions. Still, when urbanisation and industrialisation produced a working class, its Catholic elements found in the labour movement, not denominational separatism, but a way out and up within the general community.

Here developed a fluid society willing to make mutual adjustments, to teach itself to adapt to social interaction - so long as its elements played the rules, engaged in fair dealing, shared common purpose in getting and spending, and subscribed to behaviour patterns which promoted peace, security and prosperity for all. In this society it was religion itself which challenged the limits of tolerance. In so far as religion, both Catholic and Protestant, was tribal and troublemaking, it generated tension and conflict inimical to the co-operation necessary for social progress and a modem economy.

Sectarianism gave religion itself a bad name: it is the source of that distrust, suspicion, hostility, embarrassment, which is one side of Australia's religious coin. The responsibility of clergymen - and manipulative politicians - for generating and sustaining sectarian attitudes is very great. But they - at least the big names, Lang,
Parkes, Cardinal Moran, Archbishop Mannix, H. V. Evatt-had reputations very much larger than mere sectarians, claims to national greatness. Their potential for divisive provocation was curbed, not only by their own sense of proportion, but by the fact that the balance of popular consensus, the tolerance limits of the moral economy, was against it. The wish to belong together was stronger than any impulse to stay apart. Sectarianism came to be regarded as un-Australian. 